\title{
Local Intermediaries and their Organisational Identification in a French Subsidiary
}

\author{
Zølner, Mette
}

Document Version

Accepted author manuscript

Published in:

European Journal of International Management

DOI:

10.1504/EJIM.2019.096504

Publication date:

2019

License

Unspecified

Citation for published version (APA):

Zølner, M. (2019). Local Intermediaries and their Organisational Identification in a French Subsidiary. European Journal of International Management, 13(1), 88-110. https://doi.org/10.1504/EJIM.2019.096504

Link to publication in CBS Research Portal

\section{General rights}

Copyright and moral rights for the publications made accessible in the public portal are retained by the authors and/or other copyright owners and it is a condition of accessing publications that users recognise and abide by the legal requirements associated with these rights.

\section{Take down policy}

If you believe that this document breaches copyright please contact us (research.lib@cbs.dk) providing details, and we will remove access to the work immediately and investigate your claim. 


\section{Local Intermediaries and their Organisational Identification in a French Subsidiary} Mette Zolner

Journal article (Accepted manuscript*)

\section{Please cite this article as:}

Zølner, M. (2019). Local Intermediaries and their Organisational Identification in a French Subsidiary. European Journal of International Management, 131), 88-110. 001: 10.1504/EJIM.2017.10014132

\section{DOI: 10.1504/EJIM.2017.10014132}

* This version of the article has been accepted for publication and undergone full peer review but has not been through the copyediting, typesetting, pagination and proofreading process, which may lead to differences between this version and the publisher's final version AKA Version of Record.

Uploaded to CBS Research Portal: May २०19 


\title{
Local intermediaries and their organisational identification in a French subsidiary
}

\begin{abstract}
The paper explores identification processes among subsidiary employees who function as intermediaries between the subsidiary and headquarters thanks to their language competencies in the common corporate language. The study is based on a qualitative in-depth case study and adopts a social constructionist approach to identification.

The paper adds theoretically to the literature on languages in international business in three ways. First, it illustrates that fulfilling a role as local intermediary affects identification processes among subsidiary employees. Second, the paper shows that the literature on organizational identification contributes in conceptualizing local intermediaries' motivation for identification in terms of self-enhancement and sensemaking. Third, the empirical analysis indicates that feelings of self-esteem and sense-making may derive from symbolic resources for constructing workplace-related identities that prevail within the societal context of the subsidiary.

In terms of managerial relevance, the study shows the importance of identifying the subsidiary employees that fulfil roles as local intermediaries in order to recognize their efforts and to foster organizational identification. When doing so, it might be relevant to consider prevailing symbolic resources in the local context, rather than the language.
\end{abstract}

Keywords: subsidiary employees, language intermediaries, organizational identification, corporate values and procedures, qualitative study, France 


\section{Introduction}

Previously, I was a director of worldwide communication in the Group SEB. Back then, I couldn't tell the Chinese, 'Here is what you should communicate to the locals,' but I worked with the Chinese to agree on what we had to do. [...] You can work on alignment but you can never control the content of local communication $[\ldots]$ You need to rely on trust.

(Head of Communications in a French Subsidiary)

Multinational enterprises (MNEs) rely on subsidiary employees for internal communication across linguistic borders. Their proficiency in local languages and their in-depth understanding of the subsidiary's wider societal context provide them with particular competencies for assuming intermediary functions within intra-organizational communication (Caprar, 2011; Massingham, 2010; Peltokorpi and Vaara, 2012; Vance et al., 2009). Yet, drawing on these competencies implies trust, since for headquarters it is arduous to control how local employees communicate corporate messages. From the literature on translation we know that translation is a process of creative co-editing through which a translator influences the message that s/he transfers (Chidlow et al., 2014). Subsidiary employees may co-edit corporate messages creatively to make the original intent come through in a different form. However, they may also profit from their intermediary position to gain power from below by acquiring local control over meaning (Logemann and Piekkari, 2015) or for constructing a distinctive subsidiary identity (Ciuk and James, 2014). This raises the question of subsidiary employees' alignment from a headquarters perspective.

The organizational literature holds that if employees identify strongly with their organization, they are more likely to act in line with its interests and even to see self-interests as conflating with those of the focal organization (Ashforth et al., 2008; He et al., 2014). This establishes the importance of comprehending processes of organizational identification among local employees who thanks to their language capital, function as intermediaries in headquarter-subsidiary communication. Still, the emergent body of literature on languages in international business pays little attention to identification processes among this group of employees.

Literature on languages in international business defines employees who, thanks to language competencies, occupy key functions in internal communication in various roles, as language intermediaries, translators or bridging individuals (Andersen and Rasmussen, 2004; Ciuk and James, 2014; Harzing et al., 2011; Marschan-Piekkari et al., 1999a). These are roles that may be delegated formally to, or assumed informally by, expatriates, employees at headquarters or local subsidiary employees with a view to enabling communication to flow smoothly. Extant literature illustrates how MNEs may profit from local intermediaries language proficiencies on the one hand, and on the other hand, how corporate language proficiency may constitute a career capital for this group of employees that have access to more influence 
than their position and competencies would entitle to otherwise (Marschan-Piekkari et al., 1999b). However, so far, this body of literature leaves open the question of whether and how the role as an intermediary influences identification processes among the employees who fulfil this role. This is the aim of this study, which explores identification processes among subsidiary employees who act as intermediaries.

The paper explores how a group of subsidiary employees account for their role as intermediaries in communication flows between the subsidiary and headquarters. In the following they will be referred to as 'local intermediaries', in order to point out that, even though their language skills in the corporate language enable them to act as intermediaries, they see their role as one of finding compromises between global strategy and local specificities. The paper illustrates that when local intermediaries narrate their collaboration with headquarters their professional identity is at the core. Their interaction with headquarters is experienced positively or negatively depending on whether they feel recognized for competencies that they define as constituting an integral part of their professional identity.

These findings contribute theoretically to the literature on languages in international business. A first contribution is to show the need to consider identification processes among local intermediaries, as their role is likely to affect their identification either with or away from the focal organization. A second contribution is to illustrate that drawing on the literature on organizations is useful for conceptualizing feelings of recognition and meaningfulness as motives for employees' organizational identification. Third, the empirical findings indicate that for local intermediaries, such feelings might derive from symbolic resources for constructing workplace-related identities that prevail within the wider the societal context and that are situationally appropriate. This implies a need for considering the contextual embeddedness of the organization and the situation in which local intermediaries construct their identities. Finally, in terms of managerial relevance, the study illustrates the importance for an MNE, both at the corporate and subsidiary level, to identify potential local intermediaries and to care for them in order to fully draw on their language skills and local resources.

These contributions are based upon a contextually grounded qualitative case study of local intermediaries' identification processes (Brannen and Doz, 2010). The case study consists of a French subsidiary belonging to an MNE of Danish origin that uses English as its common corporate language. In the following we will use the terms "the Group" and "the Subsidiary" to preserve the anonymity of the MNE. The Subsidiary was enthusiastic when acquired by the Group, and in the post-acquisition integration phase, local employees with English skills came to function as intermediaries between the Group and the Subsidiary in which English proficiency is low. This single-case study offers a research setting that sheds light on identification processes in a national context, in which the spread of English has been the object of 
political and societal debates (Deneire, 2008), as well as being related to status loss in global organizations (Neeley, 2013; Saulière, 2014a). Therefore, one would expect the French language to become a source of identification in a situation when the local intermediaries tend to identify away from the Group during the post-acquisition phase. Yet, the local intermediaries' identification processes revolve around their professional competence. The empirical analysis was guided by the following question:

- How do the Subsidiary employees account for their role as local intermediaries?

- Why do their identification processes revolve around professional competence in the organizational and wider contexts in which they are located?

For reasons of presentational clarity, the paper outlines the theoretical framework in advance of presenting the empirical analysis and findings. However, in line with the interpretive tradition and an approach inspired by grounded theory, the study was conducted through a reiterative process alternating between collecting empirical material, analyzing and refining the theoretical framework (Charmaz, 2006; Kreiner, 2016). In this way, the article presents the study in the opposite way from how it was conducted (Suddaby, 2006).

\section{Organizational identification as self-enhancement and sense-making}

The literature on organizations advises that employees' identification is likely to influence their thoughts, feelings and actions. Therefore, organizational identification is assumed to increase the likelihood that employees act in accordance with organizational values and best interests (Kunda, 2006; Raelin, 2011; Scott, 1997. From within the literature on international organizations, Vora et al. (2007) further add that subsidiary managers fulfil their roles best when developing dual organizational identifications towards both the corporate and the subsidiary levels (Vora et al., 2007). This implies that if local intermediaries identify with the corporate level, it increases the probability that they will communicate in line with the intent of an original corporate message. In contrast, if they do not identify with the corporate level, they may disregard overall organizational goals and consider organizational subgroups (professionals, departments, teams etc.) or extra-organizational identities (nations, languages, religions, etc.) as objects for identification. Scholars point to two main types of motivation for organizational identification: self-enhancement and sense-making (Ashforth et al., 2008). Self-enhancement is when membership of the organization contributes to fulfilling employees' need for self-esteem and status. It has been found that the more personal respect and appreciation an individual feels the organization is showing, the more likely they are to identify with it (Fuller et al., 2006). Hence, positive emotional experiences of personal recognition and respect enhance organizational identification (Bartel et al., 2012; Herrbach, 2006; Oliver and Roos, 2007). Management can 
nurture employees' self-enhancement by showing recognition and respect, as this strengthens individuals' perception of their own status within the organization. The second motive is sense-making. If organizational membership supports employees in their attempts to reduce knowledge gaps and uncertainty by assigning meaning to ambiguity they are more likely to identify with the organization (Ashforth et al., 2008). Accordingly, management's behavior is crucial both when it comes to nurturing employees' feelings of meaningfulness and recognition.

This is in line with a social constructionist and interpretive stand contending that identifications are ongoing socially interactive processes through which social agents reconstruct their identities with a view to giving a positive sense to the lives they live (Bourdieu, 1979). Social actors identify with high-status groups in order to enhance their sense of self-esteem, while distinguishing themselves from groups with perceived low status. In doing so, they are likely to draw on available symbolic resources that make sense of their work task in the organization and its wider societal context. In this perspective, "bricolage" is likely to characterize identification processes since organizational members combine present elements with past experiences that they perceive as appropriate identities in the organizational environment and the situation in question. It follows that identification processes are contextually and situationally embedded within a given organizational setting and its wider societal context (Kärreman and Alvesson, 2001; Lauring 2008; Schulz et al., 2012).

In line with the social constructionist stand, intercultural studies hold that in intercultural settings, social actors negotiate meanings across national cultures in processes that lead them to define their stance vis-à-vis their own culture of origin (Brannen and Salk, 2000). Literature further illustrates that social actors also draw on a variety of symbolic resources depending on whether these are perceived as salient and situationally appropriate for constructing identities in and through social interaction in a given situation (Ailon-Souday and Kunda, 2003; Gertsen and Zølner, 2014; Sackmann and Phillips, 2004; Søderberg and Holden, 2002).

\section{Identification processes and corporate English}

The emergent body of literature on languages in international business conceives of MNEs as multilingual communities (Luo and Shenkar, 2006). Studies address the various forms of languages (e.g. national, corporate, technical) and their multifaceted role in international management processes (Brannen et al., 2014; Henderson Kassis, 2005; Lauring, 2008). Particular attention is paid to language proficiency in the common corporate language and its implications for intra-organizational knowledge flow and headquarters' control (Fredriksson et al., 2006; Harzing et al., 2011; Marschan-Piekkari et al., 1999a; 
Tietze, 2004; Welch and Welch, 2008). Reiche et al. (2015) also contend that a shared language between headquarters and subsidiary managers facilitate the development of a common social identity, however, without constituting a sufficient condition. The literature likewise demonstrates that, within MNEs, language practices establish a language hierarchy that favours employees with a language capital in the common corporate language. Employees with language competencies in corporate English (and/or in the parent language) may come to function as intermediaries (Andersen and Rasmussen, 2004; Harzing et al., 2011; Marschan et al., 1997). Their language proficiency may constitute a resource that provide access to more influence than their position and competence would normally grant them (Harzing and Pudelko, 2013; Marschan-Piekkari et al., 1999a; Neeley and Dumas, 2016; Neeley, 2013; Tietze, 2004). They may also use their position as a platform to exercise power from below by regaining local control over meaning (Logemann and Piekkari, 2015) and for constructing a distinct subsidiary identity (Ciuk and James, 2014). Conversely, local employees with no skills in the corporate language may feel silenced and excluded from career opportunities (Harzing and Feely, 2008; Marschan-Piekkari et al., 1999a; Piekkari et al., 2005). Also deficient English skills (pronunciation, grammar, vocabulary) or simply a particular accent may influence the way in which speakers are perceived (Sliwa and Johansson, 2014). Such feelings of discrimination or domination in relation to language deficiency in the corporate language might lead to suborganizational identifications in opposition to the corporate level (Fredriksson et al., 2006; Marschan-Piekkari et al., 1999a; Tietze, 2004).

Moreover, the literature suggests that the historical and social status of a language and the way in which it is spoken about is central. A common language is not neutral as it is associated with the way it is discursively constructed in and through history (Boussebaa et al. 2014; Steyaert et al., 2011; Tietze, 2004). For example, Piekkari et al. (2005) illustrate in their study on language intermediaries in a Swedish and Finnish bank merger that English is constructed discursively as a neutral language in comparison to Swedish. The merged bank adopted Swedish as the common corporate language, and Swedish-speaking Finns came to function as language intermediaries. They were favoured in the sense of achieving greater influence than their official position would have implied. However, they felt that headquarters perceived their Swedish accent as inferior and associated this with post-colonial symbolic domination. Hence, employees' willingness to adopt corporate English depends upon the extent to which they perceive it as a threat against existing linguistic identities, a symbolic domination or an enhancement of its speakers' social, economic and career opportunities. In terms of comprehending the complexity of local intermediaries' identification processes, this suggests that we also need to consider how the common language is discursively constructed within a given organizational and wider societal context. 


\section{Corporate English and identifications in a French context}

In France, the global dominance of English has been seen as a threat to the French language whose status as a national language is protected by the Toubon legislation from 1994. This legislation still mandates the use of the French language in various settings, such as in official government publications, advertisements, commercial contracts and the workplace (Deneire, 2008). The implication for private companies is that documents with information required for performing job functions, has to be in the French language, however, with the notable exception of documents sent from abroad or addressed to foreigners (Saulière, 2014a). Consequently, after thirty years with the Toubon legislation, corporate English is used by an increasing number of companies and particularly by employees with managerial responsibilities in large companies (i.e. with the French title cadres). Hence, students and their parents increasingly consider mastering English as a vital competence. English language courses are also greatly requested in the framework of vocational training, as English competency is insufficient (Díaz, 2015). It follows that speaking English is constructed as career capital in large companies. Yet, the literature also indicates that while employees are willing to adopt English to facilitate communication across borders, they are reluctant to accept the top-down imposition of English as the corporate language, since it is feared to entail exclusion and de-skilling (Deneire, 2008; Neeley, 2013; Saulière, 2014b).

Fear of status loss or dishonor is also at the core of workplace identity in French organizations according to scholars from within the literature on intercultural management. A prevailing cultural repertoire for constructing identities revolves around a founding fear of servility (Barmeyer \& Mayrhofer, 2014; Chevrier, 2011; d'Iribarne, 1989; Segal, 2014). D'Iribarne defines this cultural repertoire as a "logic of personal honor" that dates back to pre-revolutionary France, in which each estate and corporation had a codex with rights and duties to be followed to circumvent dishonor. D'Iribarne (1989) contends that remnants of the fear of dishonor remain prevalent in French workplaces today. The fear relates to being put in a position of servitude and dependence on an illegitimate power. The exercise of a profession (métier) and its recognized status constitute a shield against unworthy dependence. If employees do not receive the recognition for their profession that they consider to deserve, they are likely to reduce their work commitment or to struggle continually against their organization (Segal, 2014). According to this perspective, recognition of professional status constitutes, thus, an implicit logic in French organizations. However, this logic may give rise to various local forms of either struggle or cooperation, since the fear of unworthy dependence is "unequally distributed among employees and depend on these actors personal status or on their local recognition of "métier"' (Segal, 2014, p. 477). This insight into French cultural repertoire suggests that fear of what is perceived as servitude and/or feelings of not being professionally recognized are likely to be pivotal for identification processes within French organizational settings. 
Our review of the literature above establishes a theoretical framework for our analysis. As organizational identification creates alignment and improves performance, it is crucial to consider identification processes among local intermediaries when drawing on their language competences and local knowledge. Local intermediaries' organizational identification is likely to be fostered or impeded depending on whether they perceive their role as self-enhancing and meaningful. Social constructionist literature further suggests that organizational identifications are interactional and relational processes that are contextually embedded. This implies a need for considering the organizational context in which local intermediaries function, as well as the symbolic resources that are available and situationally appropriate for constructing workplace-related identities in the particular societal context in which the subsidiary is located. With regard to organizational contexts in France, the literature on intercultural management contends that widespread symbolic resources for sense-making and self-enhancement revolve around a fear of servitude and recognition of professional status. Finally, literature on languages indicates that the way a common language is discursively constructed has implications for whether speaking the language is seen to offer status gain or status loss. In French organizational contexts, English is a highly demanded competence; however, speaking English is often reported as something that nurtures fears of deskilling, and thus is a status loss.

\section{Methods}

\section{Research design and empirical material}

This study is designed as a qualitative in-depth case study in order to explore how local intermediaries account for their role within the organizational setting and in relation to symbolic resources that are available for constructing a salient workplace identity (Brannen and Doz, 2010). The collection and analysis of empirical material were inspired by the social constructionist approach to grounded theory, which conceives the collection of empirical material as a fluid, interactive and open-ended process during which new questions might emerge, along with increased insight into the research field (Charmaz, 2006; Suddaby, 2006). This led to distinguishing two different communication tasks in which the local intermediaries were involved. One task consisted of disseminating a set of common corporate values as a means to instill a common identity across organizational entities within the Group; a task that headquarters had formally assigned to the Subsidiaries. A second task comprised implementing corporate procedures that occurred in a second phase with a view to strengthen the Subsidiaries' global integration into the Group; a task that local employees with responsibility in those areas had taken upon themselves informally in a number of departments (i.e. human resources, communications, marketing and sales). Their conditions 
for performing the two tasks were different; while the Group left latitude for local adaption of corporate values, little if any room for local adaptions was granted in the implementation of corporate procedures.

Qualitative empirical material includes interviews, documents and observations, all of which contribute to answering the research questions. Semi-structured interviews with local employees that assume intermediary functions constitute the bulk of the empirical material (Table 1). The interviews are read as narratives in which the interviewees make sense of their role as a local intermediary and therefore, their narration provides an understanding of their identification processes (Weick, 1995). The interviews were framed by an interview guide that focused on two themes: (1) their work tasks and experiences in the Subsidiary; and (2) their experiences in implementing corporate procedures and values. Follow-up questions served to enrich their narratives with concrete examples, as well as to shed light on their collaborative experiences with the Group. All interviews were conducted in their native language, French, to ensure that language deficiency did not constrain their narrations. The analysis is based on transcripts and notes in French (Marschan-Piekkari and Reis, 2004).

To contextualize the interviewees' perceptions of their intermediary role within the organizational environment, the paper draws on various kinds of additional empirical material. Informal conversations and observations from lunch and coffee breaks shed light on concerns that the interviewees did not voice (e.g. anxiety about the future) and elaborate some of the interviewees' statements. The study also draws on semi-structured interviews conducted with local employees who did not act as intermediaries (i.e. human resources, packaging, maintenance and production) (Table 2). These interviews yielded rich insights into the Subsidiary culture within which the local intermediaries operated and thereby contributed to a contextual understanding of the organizational setting. At group level, six interviews were conducted. Questions concerned the global expansion of the Group and the process of defining and transferring corporate values. Finally, the study includes the Intranet, other internal documentation and interviews at headquarters, in order to provide insight into the corporate strategy for organizational integration and cohesion.

\section{Analysis}

In the collection process, one piece of empirical material was constantly compared with another, and emerging categories were tested against collected and ongoing interviews and observations (Charmaz, 2006; Suddaby, 2006). Initially, transcripts and notes from each interview and observation were analyzed individually. Subsequently, intertextual comparisons were made to identify similarities and differences in the interviewees' account. Technically, this was carried out using color coding combined with notes in Word documents to highlight text excerpts that illustrated prominent themes. While the coding was open initially, it gradually became more selective. First, the statements were assigned initial codings. These 
codings were then reduced to focused codings (i.e. professional expertise, autonomy, being listened to, conviviality, proximity, solidarity). This led to identifying "professional recognition" as an emergent category that captured how the interviewees described their formal or informal function as local intermediaries (Table 3).

\section{Situating and contextualizing the local intermediaries in the organizational setting}

Both the Subsidiary and the Group are in the food industry and enjoy a long history in their respective national contexts. The Group is headquartered in Copenhagen and employs approximately 45,000 people across three continents. Since the 1990s, the Group has grown from a national company into a global brand leader. At the time of the fieldwork (2012-2013), the Group defined its strategy as "glocal", in the sense of centralizing and standardizing its production and administrative procedures while remaining structured around distinct market demands with diversified products. Its global strategy can be defined as transnational in the sense of aiming at meeting high pressures for global integration as well as local responsiveness (Bartlett and Ghoshall, 1989). The Group has established English as its common corporate language while entrusting its subsidiaries to decide on their local language. This is a language design that is well suited to confront markets with diverse cultures (Luo and Shenkar, 2006).

The French Subsidiary started as an independent company, but it was first acquired by a French MNE in the 1980s, and then purchased by a British buyer in the 1990s. However, the Subsidiary continued to function autonomously until it was acquired by the Danish Group in 2008. This acquisition was received favourably by employees and managers at the Subsidiary, where the Group enjoyed the positive image of a company that pushed for improved product quality, in contrast to its previous British owner. Several interviewees voiced this positive reception by referring to the "professional" image of the Group (e.g. Table 3.1).

The ongoing integration into Group's global structures, was increasingly felt, for example through the use of corporate English (e.g. corporate documents and international working groups), although French remained the official language in the Subsidiary. In some sections with little direct Group contact (production, packaging and maintenance) communication was exclusively in French and corporate messages were translated by human resources and communications departments. However, communication with the Group took place in English in other departments, such as research and development, supply chain, human resources, communications, finance, marketing and sales. In these departments, English training represented a major part of the budget for vocational training and English skills became a requirement when recruiting new staff since, as those responsible for human resources stated, there were 
limited career opportunities for people without English proficiency. It follows the local intermediaries' English language skills positioned them favourably in the context of the integration of the Subsidiary into the global structures. However, our study illustrates that this position did not necessarily entail identification with the Group.

\section{Local intermediaries and their narrations}

In this part, we will present, first, how the interviewees account for their roles as local intermediaries in general, and second, how they experience their function in relation to two specific tasks: translating the corporate values and implementing corporate procedures.

\section{Making sense of their role as local intermediaries}

The interviewees use the word "translators" when narrating their role as local intermediaries, but without having in mind a literal translation, such as that expressed explicitly in this quote:

There are two levels of translation. One is 'I translate word for word,' and then another level, 'I translate the spirit.' This is the real translation. (Interviewee 12)

The interviewee associates this "real translation" with his profession as a communicator. A communicator takes into account the receiver and the context in order to transmit a message and even more so in corporate communication involving language translation. Therefore, getting the original intent of corporate messages through requires adaption, so that it makes sense locally. Here the interviewee emphasizes his professional knowledge when describing his role as intermediary. This is also observed in other departments, such as in sales where an interviewee describes her function as "translating" and "coordinating" in the sense of explaining the particularities of the French market to the Group and transmitting the corporate procedures to the Subsidiary.

Although the interviewees do not highlight their English proficiency, they are aware that it constitutes a career capital. Some expect that speaking English opens career opportunities, despite the fact that they are not fully proficient. When prompted on the language used in their communication with the Group, they comment briefly on feelings of being hampered by deficient English pronunciation and grammar, and also of being less accurate in English than in French. However, they sense that headquarters was indulgent regarding their language deficiency and made an effort to understand them. One even adds that getting the message through was more important than avoiding grammatical mistakes. This indicates that the interviewees do not experience English as an obstacle to collaboration, nor did they voice feelings of domination or status loss when communicating in English with headquarters. Interviews further illustrate 
that communicating in English is associated positively with belonging to an international company. One interviewee states that she is proud to be part of a global company; another that the acquisition was positive since it gave the Subsidiary an international dimension:

I work in English [...] We are in a Franco-French company. It is true that integration into an international group is a big change for most people, but I was trained in English, I was an exchange student [...] English is not a barrier for me at all. On the contrary, I see the Group's arrival as an opportunity since it gives [the company] an international dimension. (Interviewee 2)

They are attracted by the powerful international brand of the Group that is seen as promising opportunities for professional development. All have managerial responsibilities, either for a team or for a product. Some have previous professional experience from other MNEs in France and/or been exchange students (see Table 1). However, otherwise their profile is national. They are all French with an educational background primarily from French schools and universities (one exception to this national profile is an interviewee who worked for several years in Copenhagen; Interviewee 4 in Table 1). In this perspective, speaking English appears as a way to distinguish themselves within the Subsidiary and to associate themselves with internationally oriented employees in MNEs. Their recurrent use of corporate English terminology when speaking in French (e.g. "process," "challenge," "one-to-one") can be seen as an enactment of this identification.

To sum up, expectations of professional development and career opportunities are at the heart of the interviewees' account of their role as intermediaries. According to their perception, working for an international Group offers self-enhancement and this would lead us to expect identification with the Group. Yet, the study also illustrates that this self-enhancement depends on the task that they perform as intermediaries.

\section{Translating corporate values}

The Group formally delegated the implementation of its corporate values to the communications and human resources departments in all of its subsidiaries. In the French Subsidiary, this initiative coincided with the turnaround in the post-acquisition phase. One of the local intermediaries, the head of communication, saw this implementation of corporate values as an instrument to induce changes in the Subsidiary culture that was needed for the post-acquisition integration:

A successful turnaround of the company [...] actually required implementing [the corporate values] Do you mean that the implementation of [the corporate values] was part of the turnaround process? Yes, exactly. The [corporate values] were necessary to complete the mission with which we had been entrusted: the turnaround of the company. So, there was no way around it. We had to develop this culture. 
[...] It was completely in line with the Group. Therefore, I did not want this culture to come from the Group but that we told ourselves that this was the culture we needed. (Interviewee 11)

Accordingly, the head of communication decided to present the corporate values as emanating from within the Subsidiary and thus, not from the corporate level as described above. To do so, they inserted words and concepts that were easily recognizable from the Subsidiary's strategy plan from before the acquisition to visually underline coherence before and after the acquisition. Also, the French version of the corporate values was printed in the traditional color of the Subsidiary rather than that of the Group.

Moreover, a comparison between the corporate and the Subsidiary versions of the values also illustrates that they had privileged sentence structures that placed the employees on the scene as active subjects. One example is the corporate value that emphasizes a consumer-oriented culture (Table 4). The corporate version "Our customers and consumers are at the heart of every decision we make" is translated into "Nous mettons le client et le consommateur au coeur de toutes nos decisions" ("We put customers and consumers at the heart of all decisions"). This sentence structure underscores that "we, the employees" are active and sovereign actors that decide ourselves to put the customers and consumers first rather than merely being subjected to their needs and preferences, as the English version suggests. The French version also includes the sentence "Dans notre métier, le patron, c'est le consommateur et le client, le roi" ("In our profession, consumers are boss and clients are king"). Hereby, the Subsidiary translation frames the consumer and client oriented culture as being an integral part of an employee's professional competence

\section{[Insert Table 4]}

This translation resonates indeed with the professional pride that comes through when interviewees described their job functions whether they worked in marketing, sales, maintenance or on the assembly line in production and packaging. They appreciated working in the Subsidiary because it gave the possibility of "doing their job well" in a "professionally" demanding environment that offered training and opportunities for improving "professional" competence. Some interviewees describe the personal satisfaction they acquired when performing well, such as exemplified in this quote: "My motivation is to do the job as well as possible. It's a personal satisfaction" (Interviewee R). Others used the word 'passion' as exemplified here: "I am a passionate. I love leading a team and to pass on my knowledge [...] I love my job" (Interviewee J).

Pleasure and pride also come through when the local intermediaries in communication and human resources discuss their translation. They recount their reflections in relation to their translation into French and about how they creatively co-edited the translation with the intent to implement the corporate values locally; that is, in the words of the head of communication (see quote above) how they translated the 
"spirit" of the corporate values rather than just translating word-by-word. It follows that the interviewees felt that the task of implementing the corporate values offered a platform for exceling in their profession as communicators; and thus, as self-enhancing and meaningful.

\section{Implementing corporate procedures}

In the second phase of the integration into the global structures, the implementation of corporate procedures began. Local intermediaries participated in international working groups and in meetings on the procedures and subsequently communicated these to their departments, including sales, marketing, human resources and communications. The local intermediaries use words such as "painful," "difficult" and "full of tensions" when describing this implementation process.

Their frustration relates primarily to the way in which the Group went about implementing these procedures, since, as one mentions, "[...] standardization is necessary in large groups." Still, the local intermediaries expected to engage in a dialog with the Group on how to best implement the corporate procedures in the Subsidiary. This expectation is exemplified in the following quote when the interviewee defines her role as one that consists of finding a balance between the standardization to which the Group aspires and then the reality on the French market:

My role is to accompany my teams in these changes, but also to [...] lobby the Group in order to find a balance between the homogenization that it aims for and then what is efficient on the French market [...] My role is to discuss and to give the Group the information required to understand that adjustments are needed on the French market. (Interviewee 1)

Yet, in line with other interviewees, she experiences the Group as little inclined to consider French specificities. Hence, one interviewee states that "we can voice our opinion but we don't know whether we are listened to," (Interviewee 2) thereby sharing the feelings expressed by several interviewees that the Group imposed its decisions without taking into account their local insights and knowledge. Another interviewee comments that headquarters managers arrived with their PowerPoint presentations and once presented, they simply expected implementation to follow. Once the recorder was turned off, she added that the Group was like a "steam roller." A third interviewee elaborates on these tensions by commenting that

[...] headquarters managers declare 'That's how we'll do it!' They should rather start by saying 'We have an idea, how could we implement it in France?' Ultimately, I think that, they'll arrive at the same result, but things would go more smoothly. (Interviewee 4)

Her comment infers that just listening to local employees would facilitate implementation as they would understand the question as a way to appreciate their local knowledge. Also time constraints contributed to the perception that the Group had little consideration for local conditions. For example, one 
interviewee complains that corporate deadlines for the implementation of corporate procedures were decided upon without taking local deadlines into account. Moreover, as the turnaround of the Subsidiary had introduced flatter hierarchical structures, managers were more involved in daily tasks, i.e. contact with customers and clients in sales. This added to their feeling of being allocated insufficient time for exercising their profession as managers satisfactorily, as exemplified in this quote: “[...] Standardization puts a heavy burden on managers [...] and we no longer succeed in coping with both our management function [...] and our technical function [...] I don't have the support that I need today. (Interviewee 3)

Finally, one of the interviewees said that some of the corporate procedures enforced a "school boyish" behavior in the sense of obliging managers to comply with redundant formalities and reducing them to merely dutifully obeying orders. In a similar vein, another interviewee questioned the professional competence of some of the headquarter managers since these appeared more interested in implementing the procedures rather than in performing well:

French people will agree to adopt the process [in English in the original] if the one who is leading the process is a world champion. He has to be an expert. Otherwise, $[\ldots]$ things don't work well at all $[. .$. French people will say that 'your process does not work, so we have to change it. If not, we will fail.' Then, Danish people become like Germans. They'll say 'it's not possible, we need to continue following the process' [...] But is it more important to implement the process than to perform well? (Interviewee 7)

This quote suggests that headquarter managers' insistence on implementing corporate procedures uniformly leads to questioning the professional competence of the Group and thereby, to degrading the initial very positive image of the acquirer among the local intermediaries. In addition, the quote illustrates that national categories - Danish/German vs. French - are mobilized though only in a couple of instances. Few interviewees draw on such national categories when narrating the difficult implementation of the corporate procedure. This indicates that the local intermediaries did not consider national categories relevant when accounting for their function in-between the Subsidiary and the Group.

The above shows that while the interviewees expected to engage in a dialog with headquarters on how best to locally adapt procedures in France, headquarter managers insisted on rolling out the procedures uniformly. The interviewees interpret this as a lack of consideration for their local insight, and thereby also for their capacity to act competently and independently as managers. In addition, the insistences on uniformly implementing corporate procedures also made some of the interviewees question their initial image of the Group as professionally competent. 


\section{Discussion and conclusion}

In the following section, we start by summing up the findings of the empirical study; then, we discuss how these results contribute theoretically to the literature on languages in international business; and finally, we comment on managerial implications, as well as discuss the limitations of the study.

In terms of findings, our analysis shows that exercising the role of local intermediaries affected interviewees' organizational identifications. Their identification varied in relation to the tasks they fulfilled and their perception of the collaboration and communication with the Group. Accordingly, the interviewees experienced translation of the corporate values as a platform for self-enhancement, as this task allowed them to excel in their profession as communicators. Conversely, they perceived the way in which the Group implemented the corporate procedures as disrespectful. They felt that the procedures were imposed by a headquarters that appeared neither to consider whether the standardized procedures worked well in a French local context nor to value their local knowledge. Moreover, headquarter managers' insistence on standardizing the corporate procedures also degraded their initial image of the Group as embodying professional excellence. Therefore, the implementation of the corporate procedures constituted a negative emotional experience for the interviewees whose initial positive image of the Group was shattered and who did not feel that the Group recognized or respected their knowledge. Drawing on literature on organizational identification, we can say that in their interaction with the Group, the interviewees lacked self-enhancement and sense-making; two motivations for organizational identification (Ashforth et al., 2008; Fuller et al., 2006). This shows that local intermediaries' identification constituted on-going processes that were affected by how they experienced their role.

Our analysis also illustrated that when accounting for their role as local intermediaries, the interviewees' feelings of self-enhancement and sense-making were related to their profession. That is, the interviewees derived self-esteem from work tasks that provided sufficient independence for showing their professional excellence (communicative competence through translating the corporate values) while they resisted being subjected to an unworthy power (implementing corporate procedures, headquarters managers' professional competence). This shows that the interviewees' perceptions implicitly followed the logic of professional honor (Chevrier, 2011; d'Iribarne, 1989; Segal, 2014). It is not surprising in itself that their accounts of their interaction with the Group revolve around this symbolic resource. The Subsidiary is located in France and the interviewees' sociological profile leads us to assume that they have been socialized into the logic of honor in and through the French educational system; a socialization that shortterm international experiences had not defied. It is interesting, however, that rather than drawing on language as an identity marker, the interviewees mobilized the logic of honor. In this regard, they creatively combined available symbolic resources for workplace identities with the discursive construction 
of English proficiency as potentially status enhancing in corporate settings. In this respect, the study tends to confirm previous studies on the use of English in French workplaces (Deneire, 2008, Needal, 2013), showing that language anxiety and associated fears of deskilling occur primarily when employees feel that English as a common language is imposed by management. This was not the case for the interviewees that embraced the use of English as a way of distinguishing themselves positively within the subsidiary and to associate themselves with internationally oriented groups of employees in multinational enterprises. Indeed, their English skills constituted a rare and valued resource in this particular organizational context and situation, and speaking English, even deficiently, was therefore perceived as potentially career enhancing.

We argue that the findings presented above add theoretically to the literature on languages in international business in three ways. First, the findings illustrate that fulfilling a role as local intermediary affects identification processes among subsidiary employees. This points to the need for conceptualizing local intermediaries identifications, since identification with the organization is likely to improve their performance in this role (Asforth et al. 2008; He et al., 2014; Vora et al., 2007). Therefore, the study contributes to filling a gap in the literature on languages in international business that has so far paid scarce attention to identification processes among groups of employees with language proficiency in the corporate language. This literature has dealt primarily with power dynamics related to the use of a common lingua franca, that is, English. In this perspective, identification processes are seen as reactions to feelings of discrimination or domination between the employees who are deficient in corporate English, whereas identification among those who speak the dominant language is hardly explored. While our study does, indeed, confirm the pertinence of the question of power dynamics, the analysis adds that we also need to consider organizational identification among the local intermediaries who enjoy a favorable position due their language capital in the MNE, since this favorable position does not necessarily foster organizational identification. On the basis of our in-depth qualitative analysis of local intermediaries' perceptions, our study adds that feelings of meaningfulness and recognition are factors to be included when conceptualizing identification processes among subsidiary employees who interact directly with headquarters.

This leads to a second contribution. Our study shows that drawing on the literature on organizational identification and the concepts of self-enhancement and sense-making are useful. These concepts helped comprehend local intermediaries' motivations for their identification, which suggests that self-enhancement and sense-making can further our understanding of identification processes in multilingual organizations. This contributes to the discussion of the relationship between language and identity in the literature on languages in international business. Some research contends that language commonality between headquarters and subsidiaries leads to identification (Barner-Rasmussen and Björkman, 2007; Vaara et al., 2005), while others contend that a shared language may facilitate, however, without determining 
identification with the organization (Lauring, 2008; Peltokorpi \& Vaara, 2014; Reiche et al., 2015). Our analysis is in line with this latter argument, as local intermediaries' proficiency in the shared corporate language did not necessarily entail identification with the organization. Our case study contributes to this discussion on identification in multilingual organizations by illustrating the need for including consideration for whether and how social actors experience their role as meaningful and self-enhancing.

This takes us to a third contribution. We saw that when accounting for their role, the interviewees drew on a symbolic resource that, carried by French language, is recurrently employed for constructing workplace-related identities in French organizations. Thus, even though the local intermediaries perform their role thanks to their language proficiency, they did not aspire to be recognized for these skills, as their self-esteem and sense-making revolved around professional excellence. Hence, though they even enacted an identity as internationally oriented employees in and through their English proficiency, they still mobilized a symbolic resource, carried by their native language and rooted in the local societal context when making sense of their interaction with the Group. Hereby, our analysis illustrates that identity markers for local intermediaries is not per definition language as feelings of self-esteem and sense-making may derive from symbolic resources that are embedded in the societal context of a subsidiary. The epistemological implications are that contextually grounded studies with an emic approach are particularly apt for comprehending the complex and multifaceted character of identification processes in MNEs. Such an approach allows for insights into social actors' subjective experiences of their role within a global organizational, as well as into their sense making.

In terms of managerial relevance, the study suggests that it is imperative to attend to local intermediaries' self-enhancement and sense-making when drawing on their language competences and cultural resources. Their in-between position implies that they are at the core of interest conflicts between headquarters and subsidiaries, and are thereby particularly prone to feel negatively appreciated or even distrusted. Management, at a corporate as well as subsidiary level, needs to identify the tasks that local intermediaries perform and to ensure they feel recognized. Finally, the study also suggests that positive emotional feelings of appreciation and recognition are not necessarily related to local intermediaries' language resources; rather such feelings might be shaped by symbolic resources embedded in the wider societal context of the subsidiary. A consideration for the cultural context is therefore paramount.

A final remark concerns the limitations of the study and its findings. As it is based on a single indepth case study, the article does not claim to generalize about local intermediaries' identifications. The study cannot tell whether identification processes are always of importance for local intermediaries or whether they identify with or away from the focal organization. Still, the in-depth and context-specific character of the study allows for generating understanding of the factors at play in complex identification 
processes among local intermediaries that operate in-between headquarters and subsidiary. In line with its qualitative and interpretive approach, the paper does not claim that the analysis is the only possible outcome; simply that this is the most plausible interpretation. Plausibility is supported by transparency in the gathering of empirical material, analysis throughout the study and its presentation. It is indeed possible that a research design incorporating more and longer interviews would have allowed other codings to emerge. Similarly, had access been granted to observe local employees when engaging in intermediary functions, this may have provided insights that the interviewees were incapable or unwilling to voice. That said, the semi-structured interviews produced rich empirical material that, in relation to other material and extant literature on the wider organizational context, suggests patterns in the ways in which the local intermediaries accounted for their role at the time of the fieldwork.

\section{References}

Ailon-Souday, G., \& Kunda, G. (2003). The local selves of global workers: the social construction of national identity in the face of organizational globalization journal. Organization Studies, 24(7), 10731096.

Andersen, H., \& Rasmussen, E. S. (2004). The role of language skills in corporate communication. Corporate Communications: An International Journal, 9(3), 231-242.

Ashforth, B. E., Harrison, A. H., \& Corley, K. G. (2008). Identification in organizations: an examination of four fundamental questions. Journal of Management, 34(3), 325-374.

Barmeyer, C. \& Mayrhofer, U. (2014). How has the French context shaped the organization of the Airbus Group? Journal of Organizational Analysis, 22(4), 426 - 448.

Barner-Rasmussen, W., \& Björkman, I. (2007) Language fluency, socialization and inter-unit relationships in Chinese and Finnish subsidiaries. Management and Organization Review, 3(1), 105-128.

Bartel, C., Wrzesniewski, A., \& Wiesenfeld, B. (2012). Knowing where you stand: physical isolation, perceived respect, and organizational identification among virtual employees. Organization Science, 23(3), $743-757$.

Bourdieu, P. (1979). La distinction. Paris, France, Gallimard.

Boussebaa, M. Sinha, S., \& Gabriel, Y. (2014). Englishization in offshore call centers: a postcolonial perspective. Journal of International Business Studies, 45, 1152-1169.

Brannen, M. Y., \& Doz, Y. (2010). From a distance and detached to up close and personal: bridging strategic and cross-cultural perspectives in international management research and practice. Scandinavian Journal of Management, 26(3), 236-247. 
Brannen, M. Y., Piekkari, R., \& Tietze, S. (2014). The mutifaceted role of language in international business: unpacking the forms, functions and features of a critical challenge to MNC theory and performance. Journal International Business Studies, 45, 495-507.

Brannen, M. Y., \& Salk, J. (2000). Partnering across borders: negotiating organizational culture in a German-Japanese joint venture. Human Relations, 52, 451-487.

Caprar, D. V. (2011). Foreign locals: a cautionary tale on the culture on MNC local employees. Journal of International Business Studies, 42, 608-628.

Charmaz, K. (2006). Constructing grounded theory: A practical guide through qualitative analysis. Thousand Oaks, London, Sage.

Chevrier, S. (2011). Exploring the cultural context of Franco-Vietnamese development projects: using an interpretative approach to improve the cooperation process. In H. Primecz, L. Romani and S. Sackmann, Cross-cultural management in practice. Culture and negotiated meanings (41-52). Cheltenham. England, Edward Elgar.

Chidlow, A., Plakoyiannaki, E., \& Welch, C. (2014). Translation in cross-language international business research: beyond equivalence. Journal of International Business Studies, 45, 562-582.

Ciuk, S. \& James, P. (2014). Interlingual translation and the transfer of value-infused practices: an in-depth qualitative exploration. Management Learning, 46(5), 565-581.

Deneire, M. (2008). English in the French workplace: realism and anxieties. World Englishes, 27(2), 181195.

Díaz, N. R. (2015). English private tutoring in France: the race for a better job starts in advertisement campaigns. Procedia - Social and Behavioral Sciences, 173, 176-180.

D'Iribarne, P. (1989). La logique de l'honneur. Gestion des entreprises et traditions nationales. Paris, France, Seuil.

Fredriksson, R., Barner-Rasmussen, W., \& Piekkari, R. (2006). The multinational corporation as a multilingual organization: the notion of a common corporate language. Corporate Communication: An International Journal, 11(4), 406-423.

Fuller, J. B., Hester, K., Barnett, T., Frey, L., Relyea, C., \& Beu, D. (2006) Perceived external prestige and internal respect: new insights into the organizational identification process. Human Relations, 59(6), 815846.

Gertsen, M. C., \& Zølner, M. (2014). Being a 'Modern Indian' in an Offshore Centre in Bangalore: CrossCultural Contextualisation of Organisational Identification. European Journal of International Management, 8(2), 179-204.

Gioia, D. et al. 2012. Seeking Qualitative Rigor in Inductive Research: Notes on the Gioia Methodology, Organizational Research Methods, 16(1), 15-31.

Harzing, A. W., Köster, K., \& Magner, U. (2011). Babel in business: the language barrier and its solutions in the HQ-subsidiary relationship. Journal of World Business, 46(3), 279-287. 
Harzing, A. W. \& Pudelko, M. (2013). Language competencies, policies and practices in multinational corporations: a comprehensive review and comparison of Anglophone, Asian, Continental European and Nordic MNCs. Journal of World Business, 48(1), 87-97.

He, H., Pham, H. Q., Baruch, Y., \& Zhu, W. (2014). Perceived organizational support and organizational identification: joint moderating effects of employee exchange ideology and employee investment.

International Journal of Human Resource Management, 25(20), 2772-2795.

Henderson Kassis, J. (2005). Language diversity in international management teams. International Studies of Organization \& Management, 35(2), 66-82.

Herrbach, O. (2006). The affective tone of organizational commitment and identification: a matter of feeling? Journal of Organizational Behavior, 27(5), 629-643.

Kreiner, G.E. (2016). Tabula Geminus. A "Both/And” approach to coding and theorizing. In K.E. Elsbach and R.M. Kramer. (Eds.), Handbook of qualitative research. Innovative pathways and methods. (350-361). New York, NY, Routledge.

Kunda, G. (2006). Engineering culture: control and commitment in a high-tech corporation (revised edition). Philadelphia, USA, Temple University Press.

Lauring, J. (2008). Rethinking social identity theory in international encounters: language use as a negotiated object for identity making. International Journal of Cross Cultural Management, 8(3), 343-361.

Logemann, M., \& Piekkari, R. (2015). Localize or local lies? The power of language and translation in the multinational corporation. Critical Perspectives on International Business, 11(1), 30-53.

Luo, Y., \& Shenkar, O. (2006). The multinational corporation as a multilingual community: language and organization in a global context. Journal of International Business Studies, 37(3), 321-339.

Marschan, R., Welch, C., \& Welch, L. S. (1997). Language: the forgotten factor in multinational management. European Management Journal, 15(5), 591-598.

Marschan-Piekkari, R., \& Reis, C. (2004). Language and languages in cross-cultural interviewing. In R. Marschan-Piekkari and C. Welch (Eds.), Handbook of qualitative research methods for international business (224-243). Cheltenham. England, Edward Elgar.

Marschan-Piekkari, R., Welch, C., \& Welch, L. S. (1999a). In the shadow: the impact of language on structure, power and communication in the multinational. International Business Review, 8(4), 421-440.

Marschan-Piekkari, R., Welch, C., \& Welch, L. S. (1999b) Adopting a common corporate language: IHRM implications. The International Journal of Human Resource Management, 10(3), 377- 390.

Massingham, P. (2010). Managing knowledge transfer between parent country nationals (Australia) and host country nationals (Asia). International Journal of Human Resource Management, 21(9), 1414-1435.

Neeley, T. B. (2013). Language matters: status loss and achieved status distinctions in global organizations. Organization Science, 24(2), 476-497. 
Neeley, T.B. and Dumas,T.L. (2016). Unearned status Gain: Evidence from a Global Language mandate. Academy of Management Journal, 59(1), 14-43.

Oliver, D., \& Roos, J. (2007). Beyond text: constructing organizational identity multimodally. British Journal of Management, 18, 342-358.

Peltokorpi, V., \& Vaara, E. (2012). Language policies and practices in wholly owned foreign subsidiaries: a recontextualization perspective. Journal of International Business Studies, 43, 808-833.

Piekkari, R., Vaara, E., Tienari, J., \& Säntti, R. (2005). Integration or disintegration: human resource implications of a common corporate language decision in a cross-border merger. International Journal of Human Resource Management, 16, 330-344.

Raelin, J. A. (2011). The end of managerial control? Group and Organization Management, 36(2), 135160 .

Reiche, B.S., Harzing, A.-W. and Pudelko, M. (2015) Why and how does shared language affect subsidiary knowledge inflows? A social identity perspective. Journal of International Business Studies, 46(5), 528551.

Sackmann, S., \& Phillips, M. E. (2004). Contextual influences on culture research: shifting assumptions for new workplace realities. International Journal of Cross-Cultural Management, 4(3), 370-390.

Saulière, J. (2014a). Corporate language: the blind spot of language policy? Reflections on France's Loi Toubon. Current Issues in Language Planning, 15(2), 220-235.

Saulière, J. (2014b). Anglais correct exigé : Dynamiques et enjeux de l'anglicisation dans les entreprises françaises. Ph.D. thesis defended at Ecole Polytechnique, July 72014.

Schulz, M., Maguire, S., Langley, A., \& Tsoukas, H. (2012). Constructing identity in and around organizations. Oxford, England, Oxford University Press.

Scott, C. R. (1997). Identification with multiple targets in a geographically dispersed organization. Management Communication Quarterly, 10(4), 491-522.

Segal, J.-P. (2014). Gestion \& société approach to cooperation of French firms. International Journal of Organizational Analysis, 22(4), 470-485.

Sliwa, M., \& Johansson, M. (2014). How non-native English-speaking staff are evaluated in linguistically diverse organizations: a sociolinguistic perspective. Journal of International Business Studies, 45(9), 11331151.

Søderberg, A.-M., \& Holden, N. (2002). Rethinking cross-cultural management in a globalizing business world. International Journal of Cross-Cultural Management, 2(1), 103-121.

Steyaert, C., Ostendorp, A., \& Gaibrois, C. (2011). Multilingual organizations as 'linguascapes': negotiating the position of English through discursive practices. Journal of World Business, 46(3), 270278. 
Suddaby, R. (2006). From the editors: what grounded theory is not. Academy of Management Journal, 49(4), 633-642.

Tietze, S. (2004). Spreading the management gospel - in English. Language and Intercultural Communication, Multilingual Matters, 4(3), 175-189.

Vaara, E., Tienari, J., Piekkari, R., \& Säntti, R. (2005). Language and the circuits of power in a merging MNC. Journal of Management Studies, 42(3), 595-623.

Vance, C. M., Vaiman, V., \& Andersen, T. (2009). The vital liaison role of host country nationals in MNC knowledge management. Human Resource Management, 48(4), 649-659.

Weick, K. E. (1995). Sensemaking in organizations. London, England, Sage Publications.

Welch, D. E., \& Welch, L. S. (2008). The importance of language in international knowledge transfer. Management International Review, 48(3), 339-360.

Table 1 Interviewees that assume functions as local intermediaries (formally and informally)

\begin{tabular}{|l|l|l|l|l|}
\hline & Position & Education & $\begin{array}{l}\text { Previous professional } \\
\text { experience }\end{array}$ & Interview \\
\hline 1. & Sales & $\begin{array}{l}\text { French school of } \\
\text { management (Province) }\end{array}$ & Nestlé (France) & $\begin{array}{l}\text { January } \\
2013\end{array}$ \\
\hline 2. & Sales & $\begin{array}{l}\text { French school of } \\
\text { management (Province) }\end{array}$ & Mars (France) & $\begin{array}{l}\text { January } \\
\text { 3. }\end{array}$ \\
\hline 4. & Males & $\begin{array}{l}\text { French school of } \\
\text { management (Province) }\end{array}$ & Unknown & $\begin{array}{l}\text { January } \\
2013\end{array}$ \\
\hline 5. & Marketing & $\begin{array}{l}\text { French (Paris) and } \\
\text { Canadian university }\end{array}$ & $\begin{array}{l}\text { Group's headquarter } \\
\text { (Copenhagen) }\end{array}$ & $\begin{array}{l}\text { January } \\
2013\end{array}$ \\
\hline
\end{tabular}




\begin{tabular}{|c|l|l|l|l|}
\hline 7. & $\begin{array}{l}\text { Human } \\
\text { Resources }\end{array}$ & $\begin{array}{l}\text { French university } \\
\text { (Province) }\end{array}$ & Unknown & $\begin{array}{l}\text { January, } \\
2012\end{array}$ \\
\hline 9. & $\begin{array}{l}\text { Human } \\
\text { Resources }\end{array}$ & $\begin{array}{l}\text { French school of } \\
\text { management (Province) }\end{array}$ & None & $\begin{array}{l}\text { February } \\
2013\end{array}$ \\
\hline 11. & Communications & $\begin{array}{l}\text { French school of } \\
\text { management (Province) }\end{array}$ & SEB (France) & January \\
\hline 12. & Communications & French university (Paris) & Kingfisher (France) & January \\
& & & & 2012 \\
\hline
\end{tabular}

Table 2 Other interviewees in the Subsidiary (Fabrication, Maintenance and Packaging)

\begin{tabular}{|l|l|l|l|l|}
\hline & Position & Education & $\begin{array}{l}\text { Previous } \\
\text { professional } \\
\text { experience }\end{array}$ & Interview \\
\hline A. & $\begin{array}{l}\text { Human } \\
\text { Resources }\end{array}$ & $\begin{array}{l}\text { French university } \\
\text { (Province) }\end{array}$ & None & May 2012 \\
\hline B. & Human Resources & $\begin{array}{l}\text { French university } \\
\text { (Province) }\end{array}$ & Lilly, (France) & January 2013 \\
\hline C. & Fabrication & Vocational & Heineken, (France) & \\
\hline D. & Fabrication & On-the-job training & Unknown & May 2012 \\
\hline E. & $\begin{array}{l}\text { Team-leader, } \\
\text { Fabrication }\end{array}$ & Vocational & None & May 2012 \\
\hline F. & Fabrication & On-the-job training & None & May 2012 \\
\hline G. & Fabrication & On-the-job training & None & January 2013 \\
\hline H. & Fabrication & On-the-job training & Unknown & \\
\hline
\end{tabular}




\begin{tabular}{|c|c|c|c|c|}
\hline I. & Packaging & Vocational & None & January 2013 \\
\hline $\mathbf{J}$. & Packaging Manager & On-the-job training & None & January 2013 \\
\hline $\mathbf{K}$. & Packaging Team-leader & On-the-job training & None & January 2013 \\
\hline L. & Packaging & On-the-job training & None & January 2013 \\
\hline M. & Packaging & On-the-job training & Unknown & January 2013 \\
\hline $\mathbf{N}$. & Maintenance & Vocational & Unknown & January 2013 \\
\hline O. & Maintenance & Vocational & Alcatel & May 2012 \\
\hline $\begin{array}{l}\mathbf{P} \\
\text {. }\end{array}$ & Maintenance & Vocational & SME, Lilly & May 2012 \\
\hline Q. & Maintenance & Vocational & None & May 2012 \\
\hline R. & Maintenance & Vocational & None & May 2012 \\
\hline S. & Maintenance & Vocational & Unknown & May 2012 \\
\hline R. & $\begin{array}{l}\text { Maintenance Team- } \\
\text { leader }\end{array}$ & Vocational & None & May 2012 \\
\hline S. & Maintenance & Vocational & SME & January 2013 \\
\hline T. & Maintenance & Vocational & Henkel & January 2013 \\
\hline $\mathbf{U}$ & Manager & Vocational & Unknown & January 2013 \\
\hline
\end{tabular}


Table 3 Codings illustrating the conceptual category 'professional recognition' (elaborated with inspiration from Gioia et al., 2012)

\begin{tabular}{|c|c|c|c|}
\hline $\begin{array}{l}\text { Selected quotes from interviews with } \\
\text { local intermediaries } \\
\text { (number in () refers to the } \\
\text { interviewees in Table 1) }\end{array}$ & Initial codings & $\begin{array}{l}\text { Focused } \\
\text { codings }\end{array}$ & $\begin{array}{l}\text { Conceptual } \\
\text { category }\end{array}$ \\
\hline $\begin{array}{l}\text { 3.1 What was good was that [the Group] } \\
\text { shared the culture related to our } \\
\text { [profession]. We were walking out of an } \\
\text { experience that was financial [he refers } \\
\text { to the previous owner]. We were } \\
\text { traumatized. The acquisition was a } \\
\text { relief. (7) }\end{array}$ & $\begin{array}{l}\text { The Group shares } \\
\text { the same profession }\end{array}$ & \multirow{3}{*}{$\begin{array}{l}\text { Group and } \\
\text { the } \\
\text { Subsidiary } \\
\text { are } \\
\text { professionally } \\
\text { competent } \\
\text { organizations }\end{array}$} & \multirow{4}{*}{$\begin{array}{l}\text { Professional } \\
\text { recognition }\end{array}$} \\
\hline $\begin{array}{l}3.2[\ldots] \text { belonging to an international } \\
\text { group is reassuring, because we have } \\
\text { the means to work, we have structures, } \\
\text { we have teams that reflect well on } \\
\text { marketing [...].(5) }\end{array}$ & $\begin{array}{l}\text { An international } \\
\text { company provides } \\
\text { structures for } \\
\text { performing well } \\
\text { professionally. }\end{array}$ & & \\
\hline $\begin{array}{l}3.3[\ldots] \text { The level of demand is higher } \\
\text { here [name of the Subsidiary]. }[\mathrm{My}] \text { job } \\
{[\ldots] \text { pushes my skills further }[\ldots]} \\
\text { It gives you opportunities for } \\
\text { development? } \\
\text { That's it, and beyond development, I } \\
\text { learn more in the field of my profession } \\
\text { [...].(2) }\end{array}$ & $\begin{array}{l}\text { The Subsidiary } \\
\text { provides structures } \\
\text { for developing } \\
\text { professional } \\
\text { competence }\end{array}$ & & \\
\hline $\begin{array}{l}\text { 3.4 The Group wants to consider the } \\
\text { local. It's motivating for } \\
\text { employees.(6) }\end{array}$ & $\begin{array}{l}\text { The Group aspires } \\
\text { to consider local } \\
\text { knowledge }\end{array}$ & & \\
\hline
\end{tabular}




\begin{tabular}{|c|c|c|}
\hline $\begin{array}{l}\text { 3.5 As long as we can express } \\
\text { ourselves, it's fine. [...] (5) }\end{array}$ & Voice is possible & $\begin{array}{l}\text { Being listened } \\
\text { to }\end{array}$ \\
\hline $\begin{array}{l}\text { 3.6 It is important to have local } \\
\text { correspondents (in English in the } \\
\text { original) }[\ldots] \text { who }[\ldots] \text { are capable of } \\
{[\ldots] \text { translating the corporate intentions }} \\
\text { for the Subsidiary. (11) }\end{array}$ & $\begin{array}{l}\text { Corporate } \\
\text { knowledge needs to } \\
\text { be translated into } \\
\text { local structures }\end{array}$ & \\
\hline $\begin{array}{l}\text { 3.7 [...] If we want to pursue our } \\
\text { integration successfully within the } \\
\text { Group we need people who speak } \\
\text { English. It's good for them because } \\
\text { someone who does not speak English } \\
\text { will be unhappy with us, since they } \\
\text { cannot contribute with all their expertise } \\
\text { and cannot be open to the Group spirit. } \\
\text { And for the sake of the company we } \\
\text { need people who speak English. (9) }\end{array}$ & $\begin{array}{l}\text { English proficiency } \\
\text { is required for } \\
\text { contributing with } \\
\text { one's expertise }\end{array}$ & \\
\hline $\begin{array}{l}\text { 3.8 As managers we are more involved } \\
\text { in the daily tasks and we don't have } \\
\text { time for managing. ( } 3 \text { ) }\end{array}$ & $\begin{array}{l}\text { Insufficient time } \\
\text { for carrying out our } \\
\text { profession }\end{array}$ & \multirow{3}{*}{$\begin{array}{l}\text { Group } \\
\text { integration } \\
\text { constrains } \\
\text { professional } \\
\text { performance }\end{array}$} \\
\hline $\begin{array}{l}\text { 3.9. We already [have] tools that work } \\
\text { very well [...] But they want the same } \\
\text { thing everywhere and we [...] do not } \\
\text { have time to redevelop tools [...]. (1) }\end{array}$ & $\begin{array}{l}\text { Headquarters } \\
\text { leaders impose } \\
\text { harmonization } \\
\text { without granting } \\
\text { time }\end{array}$ & \\
\hline $\begin{array}{l}\text { 3.10 French people agree to adopt the } \\
\text { process [in English in the original } \\
\text { French quote] if the one who is leading } \\
\text { the process is a world champion. He has } \\
\text { to be an expert. Otherwise, }[\ldots] \text { things } \\
\text { don't work out at all [...].(7) }\end{array}$ & $\begin{array}{l}\text { Headquarters } \\
\text { leaders are not } \\
\text { experts }\end{array}$ & \\
\hline
\end{tabular}


Table 4 Translated and original version of one corporate value

\begin{tabular}{|c|c|}
\hline $\begin{array}{c}\text { Nous mettons le client et le consommateur au } \\
\text { caur de toutes nos décisions }\end{array}$ & $\begin{array}{c}\text { Our customers and consumers are at the } \\
\text { heart of every decision we make }\end{array}$ \\
\hline $\begin{array}{l}\text { Dans notre métier, le patron c'est le } \\
\text { consommateur et le client est roi : nous sommes } \\
\text { en permanence à leur écoute et nous définissons } \\
\text { notre stratégie en fonction de leurs besoins. Nous } \\
\text { travaillons continuellement pour améliorer leur } \\
\text { expérience de nos marques et de nos services. } \\
\text { Notre objectif: rendre nos consommateurs fans et } \\
\text { nos clients accros. }\end{array}$ & $\begin{array}{l}\text { We put ourselves in the shoes of our consumers } \\
\text { and customers and have detailed insight into } \\
\text { their needs and preferences. We base our } \\
\text { strategies and plans on this insight and } \\
\text { continuously evaluate the ways we work to } \\
\text { improve their experience of our brands, our } \\
\text { services and our people. }\end{array}$ \\
\hline
\end{tabular}

